\title{
Growth Factors and Taurine Protect against Excitotoxicity by Stabilizing Calcium Homeostasis and Energy Metabolism
}

\author{
Abdeslem El Idrissi and Ekkhart Trenkner \\ New York State Institute for Basic Research in Developmental Disabilities, Center for Developmental Neuroscience, The \\ Graduate School and University Center of the City University of New York, Staten Island, New York 10314
}

Taurine, brain derived neurotrophic factor (BDNF), and basic fibroblast growth factor (bFGF) are known to control the development of early postnatal cerebellar granule cells. This study attempted to investigate possible mechanisms of this control by determining neuronal survival, calcium homeostasis, and related calcium-mediated functions, as well as the site of action during glutamate-induced excitotoxicity in cultures of cerebellar granule cells. We report that stimulation of glutamate receptors induced a rapid increase in intracellular calcium concentrations $\left(\left[\mathrm{Ca}^{2+}\right]_{i}\right)$ and a decrease in mitochondrial energy metabolism. These effects of glutamate were time- and concentration-dependent and could be specifically blocked by glutamate receptor antagonists. Taurine and bFGF but not BDNF differently regulated $\left[\mathrm{Ca}^{2+}\right]_{i}$, and preserved the mitochondrial energy metabolism in the presence of glutamate. The regulation of $\left[\mathrm{Ca}^{2+}\right]_{\mathrm{i}}$ by bFGF and taurine required pretreatment

The development and maintenance of the CNS are regulated by a balanced interaction of multiple factors. Slight alterations in the relative expression of any one signal or combination thereof can result in significant functional and structural neuronal changes and might, under certain conditions, lead to pathological states and cell death.

Glutamate is the major excitatory neurotransmitter in mammalian brain (Watkins and Evans, 1981; Olney et al., 1987). Activation of glutamate receptors causes extracellular calcium influx and mobilization of additional calcium from intracellular stores (Jaffe and Brown, 1994). Calcium serves physiologically important functions as second messenger (Lynch et at., 1983; Kater et al., 1988). However, excessive elevation of intracellular calcium levels results in structural damage to neurons (Beal et al., 1993; Mattson, 1994; Macaya et al., 1996; Stout et al., 1998). Thus, the control of intracellular calcium concentrations is a fundamental process in neuronal survival and function (Choi, 1990; Dykens et al., 1987; Siesjo, 1988; Mattson, 1992).

Recently, mechanisms have been described involving growth factors (GFs) that protect neurons from excitotoxicity (Pechan et al., 1992; Mattson and Cheng, 1993; El Idrissi et al., 1998). GFs

\footnotetext{
Received June 4, 1999; revised Aug. 13, 1999; accepted Aug. 20, 1999.

This study was supported in part by funds from the New York State Office of Mental Retardation and Developmental Disabilities and the Center of Developmental Neuroscience and Developmental Disabilities. We are grateful to Drs A. Rabe, T. Lidsky, and M. Quinn for their time to critically read and discuss this manuscript with us and for their suggestions to make it readable.

Correspondence should be addressed to Dr. Ekkehart Trenkner, Institute for Basic Research in Developmental Disabilities, 1050 Forest Hill Road, Staten Island, NY 10314. E-mail: trenkner@postbox.csi.cuny.edu and trenkner@hotmail.com. Copyright (C) 1999 Society for Neuroscience 0270-6474/99/199459-10\$05.00/0
}

of cells with these factors. Confocal microscope analysis of $\left[\mathrm{Ca}^{2+}\right]_{\mathrm{i}}$ and ${ }^{45} \mathrm{Ca}^{2+}$ uptake studies showed that bFGF reduced the magnitude of glutamate-induced calcium uptake with no apparent regulation thereafter. Taurine, on the other hand, did not affect the level of calcium uptake induced by glutamate but rather the duration of the maximal response; this maximal response was transient and returned to basal levels $\sim 10 \mathrm{~min}$ after glutamate receptor stimulation. We conclude from these data that bFGF and taurine prevent glutamate excitotoxicity through regulation of $\left[\mathrm{Ca}^{2+}\right]_{i}$ and mitochondrial energy metabolism. Furthermore, the neuroprotective role of taurine and bFGF was enhanced by their collaboration.

Key words: cerebellar granule cells; excitotoxicity; growth factors; taurine; glutamate; calcium; energy metabolism; BDNF; bFGF

regulate the development, maintenance, and survival of neurons (Barde, 1989) and are implicated in neuronal functions. These processes are generally mediated through autophosphorylation of cell surface receptors, leading to various transcriptional events (Chao, 1992; Barbacid, 1994; Greene and Kaplan, 1995; Bothwell, 1996).

We have shown that taurine (2-aminoethanesulfonic acid) plays a major role in modulating glutamate-induced signaling events (Trenkner, 1990; Trenkner et al., 1996; El Idrissi et al., 1998). Taurine prevented excitotoxicity in vitro (Trenkner and Dykens, 1986; Trenkner, 1990), suggesting that the neuroprotective effect of taurine, as well as GFs, may be mediated primarily through modulation of intracellular calcium homeostasis.

Energy metabolism is recognized as one of the fundamental processes necessary for the maintenance of neuronal structures and functions (Mattson et al., 1993; Beal, 1995). The activity of the mitochondrial electrochemical gradient (MtECG) and the amount of energy it produces are calcium-regulated (Hertz et al., 1988; White and Reynolds, 1995; Budd and Nicholls, 1996). Furthermore, mitochondria may be involved in glutamate toxicity (Schinder et al., 1996; White and Reynolds, 1996). Because the mitochondria have large capacity for calcium uptake (Nicholls and Akerman, 1982; Gunter et al., 1994), they might have a neuroprotective role by removing calcium from the cytoplasm (Budd and Nicholls, 1996; Stout et al., 1998). Mitochondria also have been found to be essential in controlling certain apoptotic pathways (Green and Reed, 1998) through the release of caspase activators, such as cytochrome c (Liu et al., 1996) and apoptosisinducing factors (Susin et al., 1996). We and others have demonstrated that depletion of cellular energy levels increased the 
vulnerability toward excitotoxins, leading to cell death (Budd and Nicholls, 1995; Trenkner et al., 1996; Schinder et al., 1996).

This study shows that a sustained rise in intracellular calcium levels and a decrease in MtECG were primarily responsible for the degenerative actions of glutamate, which can be controlled through different mechanisms by taurine and basic fibroblast growth factor (bFGF).

\section{MATERIALS AND METHODS}

Brain derived neurotrophic factor (BDNF) and bFGF were obtained from Promega (Madison, WI). Minimum essential medium (MEM), horse serum (HS), fetal calf serum (FCS), penicillin, streptomycin, and $\mathrm{N}-2$ supplement were purchased from Life Technologies (Grand Island, NY). Culture dishes were obtained from Falcon (Lincoln Park, NJ). Trypsin and DNase were purchased from Worthington (Freehold, NJ). NMDA, kainate, and MK-801 came from Tocris Cookson (Bristol, UK). Fluo-3, fluorescein diacetate (FDA), and propidium iodide (PI), were obtained from Molecular Probes (Eugene, OR). Percoll, Triton X-100, cytosine arabinoside (Ara C), poly-D-lysine (PDL), rhodamine 123, taurine, and glutamate were obtained from Sigma (St. Louis, MO). ${ }^{45} \mathrm{CaCl}_{2}$ was received from Amersham Pharmacia Biotech (Arlington Heights, IL). All other chemicals were of high-quality cell culture grade.

Cell preparation and culture conditions. The development of cerebellar granule neurons in vitro depends on growth conditions. To characterize the role of glial cells and exogenously added growth factors on the survival and function of granule neurons, we used four culture conditions, as follows. (1) Mixed cultures: Cerebellar granule cells were prepared from 7-d-old mice as described previously (Trenkner and Sidman, 1977; Trenkner, 1991). Briefly, the entire cerebellum was removed, and single cell suspensions were prepared by trypsinization and trituration in $1 \%$ trypsin in $\mathrm{Ca}^{2+}-\mathrm{Mg}^{2+}$-free isotonic phosphate buffer (CMF-PBS). Cells were washed in CMF-PBS and resuspended in culture medium (MEM), supplemented with $0.25 \%$ glucose, $2 \mathrm{~mm}$ glutamine, $10 \% \mathrm{HS}, 5 \% \mathrm{FCS}$, and $25 \mathrm{U} / \mathrm{ml}$ both penicillin and streptomycin. Cells were seeded into PDL-coated dishes and incubated at $37^{\circ} \mathrm{C}$ in a moist chamber under 5\% $\mathrm{CO}_{2}$. (2) Enriched neuronal cultures: Mixed cultures were prepared as described above, but after $24 \mathrm{hr}$ in vitro the medium was replaced with serum-free medium containing $15 \% \mathrm{~N}-2$ supplement (Bottenstein et al., 1980), consisting of $100 \mu \mathrm{g} / \mathrm{ml}$ transferrin, $20 \mu \mathrm{g} / \mathrm{ml}$ putrescine, $12.8 \mathrm{ng} / \mathrm{ml}$ progesterone, $10.4 \mathrm{ng} / \mathrm{ml}$ selenium, $25 \mathrm{ng} / \mathrm{ml}$ insulin, and $0.8 \mathrm{ng} / \mathrm{ml}$ thyroxine. The mitotic inhibitor Ara $\mathrm{C}$ was added during medium exchange $(2 \mu \mathrm{M})$; this curtailed the number of astrocytes that develop in cultures. The cultures were maintained in a humidified $5 \% \mathrm{CO}_{2}-95 \%$ air atmosphere at $37^{\circ} \mathrm{C}$ in slightly modified MEM with elevated glucose $(30 \mathrm{~mm})$ and reduced glutamine (0.8 mM) concentration (Peng et al., 1991). (3) Purified neurons in serum-containing medium: Cells were obtained from 3- or 4-d-old mice, and single-cell suspensions were prepared as described above. Granule neurons were purified in a Percoll gradient (35-65\%) based on cellular size and selective adhesiveness of neurons and glial cells to plastic (for review, see Trenkner, 1991). (4) Purified neurons in serum-free medium: Cultures were prepared as above and seeded in serum-containing medium for $24 \mathrm{hr}$, and medium was replaced by serum-free medium consisting of MEM supplemented with 15\% N-2. Although these cell preparations were almost free of non-neuronal cells, the number of cerebellar granule cells after gradient separation was insufficient for most of the experiments described. Therefore, these four culture conditions were used only to confirm the role of glial cells in vitro. Most of the experiments were conducted in enriched neuronal cultures (condition 2) in which the number of non-neuronal cells was significantly reduced.

Assessment of cell survival. We have used both morphological and biochemical markers to determine cell viability. Morphological assessment was as follows. When growing in monolayer, the integrity of presumptive neurons, glia, and fibroblasts was appraised on the basis of morphology and phase-refraction characteristics using phase-contrast microscopy (Trenkner and Sidman, 1977; Hatten, 1985). Neurons were scored as viable if they had neurites that were smooth in appearance and cell bodies that were smooth and round-to-oval in shape. In degenerating neurons, neurites were fragmented and beaded, and the soma was rough, swollen, vacuolated, and irregular in shape. The percentages of live neurons represent counts of all presumptive granule neurons within two randomly chosen rectangular fields encompassing almost $60 \%$ of the total well area.

Intravital staining of cultured neurons was performed using the method of Faravon et al. (1988). Living cells were labeled with FDA (15 $\mu \mathrm{g} / \mathrm{ml})$, whereas the nuclei of dead cells were labeled with PI $(4.5 \mu \mathrm{g} / \mathrm{ml})$, which interacts with DNA to yield a bright red fluorescent complex. Cells were immediately observed with a standard epi-illumination fluorescent microscope (450 excitation., 520 barrier). Three to four fields containing $\sim 200$ cells were examined.

Activity of the mitochondrial electrochemical gradient. Quantitative determination of rhodamine 123 uptake was as follows. As described by Chen (1989), a stock solution $(1 \mathrm{mg} / \mathrm{ml})$ of rhodamine 123 was prepared in DMSO and stored at $4^{\circ} \mathrm{C}$. After treatment, medium was removed, and rhodamine 123 was added to a final concentration of $10 \mu \mathrm{g} / \mathrm{ml}$. After 30 $\min$ at $37^{\circ} \mathrm{C}$, the cultures were washed three times in the growth medium. To release accumulated rhodamine from cells, $2 \mathrm{ml}$ of butanol was added to each culture dish and incubated at room temperature for $1 \mathrm{hr}$. Cellular accumulation of rhodamine 123 was determined using a spectrofluorometer with the excitation wavelength set at $508 \mathrm{~nm}$ and emission wavelength set at $536 \mathrm{~nm}$ and was normalized to total protein concentration.

${ }^{45} \mathrm{Ca}^{2+}$ accumulation. Cells were washed twice with Locke's solution containing (in mM): $154 \mathrm{NaCl}, 5.6 \mathrm{KCl}, 3.6 \mathrm{NaHCO}_{3}, 1.3 \mathrm{CaCl}_{2}, 5.6$ glucose, and $5 \mathrm{~mm}$ HEPES, $\mathrm{pH}$ 7.4. Additions were made to a final volume of $0.25 \mathrm{ml}$ including $2 \times 10^{5} \mathrm{cpm}$ of ${ }^{45} \mathrm{CaCl}_{2}$, which was added $10 \mathrm{sec}$ before the addition of the agonist. After $20 \mathrm{~min}$ (or as indicated) at room temperature, the cells were rapidly washed three times in $0.5 \mathrm{ml}$ of Locke's solution containing $2 \mu \mathrm{M}$ MK-801. High concentration of MK-801 was used in the ${ }^{45} \mathrm{Ca}^{2+}$ uptake assay to ensure fast channel block. Finally, the total amount of ${ }^{45} \mathrm{Ca}^{2+}$ was determined in the lysate after the cells were dissolved in $0.5 \mathrm{ml}$ of $0.1 \mathrm{M} \mathrm{NaOH}$. All ${ }^{45} \mathrm{Ca}^{2+}$ uptake determinations were measured in triplicate.

Calcium imaging. Quantitative measurements of intracellular calcium concentration $\left(\left[\mathrm{Ca}^{2+}\right]_{\mathrm{i}}\right)$ were performed in morphologically identified cerebellar granule cells grown on PDL-coated coverslips for $4 \mathrm{~d}$. Stock solution $(1 \mathrm{mM})$ of the acetoxymethylester fluo-3 was prepared in anhydrous DMSO and stored desiccated at $-20^{\circ} \mathrm{C}$. Cells were loaded with fluo-3 $(5 \mu \mathrm{M})$ for $30 \mathrm{~min}$ at $37^{\circ} \mathrm{C}$ in $1 \mathrm{ml}$ of magnesium-free Locke's solution. Subsequently, cells were rinsed with Locke's solution, and coverslips were mounted into the recording chamber. To achieve rapid and even distribution, $0.5 \mathrm{ml}$ of the compounds to be tested were added in double concentration to $0.5 \mathrm{ml}$ of Locke's solution in the recording chamber.

Confocal images of cellular fluorescence were obtained using a Nikon (Tokyo, Japan) inverted epifluorescence microscope equipped with an oil immersion $60 \times, 1.4$ NA objective. The excitation wavelength used was $488 \mathrm{~nm}$, and the emission wavelength was $505 \pm 30 \mathrm{~nm}$. In all experiments, fluorescence was measured in cell somata rather than neurites. All recordings were performed at room temperature $\left(22-25^{\circ} \mathrm{C}\right)$. Background fluorescence values, determined in cell-free regions of each coverslip, were subtracted from all values.

At the end of each experiments, fluorescence intensities were calibrated to determine $\left[\mathrm{Ca}^{2+}\right]_{\mathrm{i}}$. Maximal fluorescence value $\left(F_{\max }\right)$ was determined by permeabilizing cells with $1 \%$ Triton $\mathrm{X}-100$ to attain the saturation level of binding with the trapped fluo-3. Subsequently, the minimum fluorescence value $\left(F_{\min }\right)$ was measured in the presence of $10 \mathrm{~mm}$ EGTA to chelate all the free calcium. The free cytosolic calcium concentration was then calculated using the following equation: $\left[\mathrm{Ca}^{2+}\right]_{\mathrm{i}}=K_{\mathrm{d}}\left(F-F_{\min }\right) /\left(F_{\max }-F\right)$ (Grynkiewicz et al., 1985; Kao, 1994; Veliçelebi et al., 1998; Lin et al., 1999; Mestdagh and Wülfert, 1999 ), where $F$ is the observed fluorescence value in intact cells. An equilibrium dissociation constant $\left(K_{\mathrm{d}}\right)$ of $390 \mathrm{~nm}$ was used for fluo-3. The calibration procedure described here is based on the assumption that the fluorescence properties $\left(F_{\min }\right.$ and $\left.F_{\max }\right)$ and the $K_{\mathrm{d}}$ of the indicator are the same in cells as in vitro.

Protein determination. Protein concentrations were determined by the method of Bradford (1976) using bovine serum albumin as standard protein (Bio-Rad, Hercules, CA).

Statistical analysis. Multifactorial ANOVA and ANCOVA were used to identify overall condition effects. Significant changes were determined by post hoc comparisons of means using Tukey's honest significant difference test. Significance was set at a confidence level of $95 \%$. Data are presented as mean \pm SEM. 


\section{RESULTS}

\section{bFGF and taurine attenuate glutamate-induced excitotoxicity}

The neuroprotective effects of bFGF and taurine against glutamate excitotoxicity were assessed under four different culture conditions (see Materials and Methods) (Fig. 1). We confirmed that neuronal survival was dependent on astroglial cells (Trenkner and Sidman, 1977; Hatten et al., 1988; Trenkner, 1991; Rosenberg, 1991), because the highest degree of neuronal survival was reached in serum-supplemented medium containing neurons and glial cells (Fig. 1A). Under these culture conditions, bFGF, with or without taurine, had little effect on neuronal survival.

One millimolar glutamate significantly reduced the number of surviving granule neurons under every culture condition examined (Fig. 1 $A-D$ ). This excitotoxic effect of glutamate was more pronounced in cultures of purified or enriched cerebellar neurons than in mixed cultures, suggesting a protective role of astroglia during glutamate excitotoxicity (Rosenberg and Li, 1995). bFGF and/or taurine had little effect on neuronal survival in mixed cerebellar cultures but improved neuronal survival of purified granule cells significantly in numbers similar to controls (Fig. 1C), suggesting that these factors can replace the role of astrocytes. In serum-free medium, on the other hand, the highest neuroprotection against glutamate excitotoxicity was observed only when taurine and high concentrations of bFGF were combined, although both factors alone could not prevent glutamate-induced cell death (Fig. 1D). Thus, taurine can support bFGF function under certain conditions.

Taurine and bFGF did not act synergistically nor additively in the presence of glutamate, but rather both factors were capable of providing optimal cell survival. However, under serum-free conditions, neuroprotection was obtained only through collaboration of taurine and bFGF. Because both factors act through different mechanisms, a variety of alternative mechanisms might be activated to control cell survival.

\section{Intracellular calcium accumulation as a function of glutamate receptor activation}

Because increases in intracellular calcium have been implicated in excitotoxic cell death in several different paradigms (Dykens et al., 1987; Choi, 1988; Mattson et al., 1988; Siesjo, 1988; Mattson, 1992; Stout et al., 1998) and because elevation in intracellular calcium is known to mediate the glutamate-induced excitotoxicity, we performed experiments to determine the intracellular accumulation of ${ }^{45} \mathrm{Ca}^{2+}$ in the presence of increasing concentrations of glutamate receptor agonists. Figure 2 shows that ${ }^{45} \mathrm{Ca}^{2+}$ accumulation in enriched granule cell cultures under serum-free conditions depended on concentrations of extracellular glutamate or NMDA but not on kainate concentrations. Depolarization with $1 \mathrm{~mm}$ glutamate or NMDA for $15 \mathrm{~min}$ induced a significant ${ }^{45} \mathrm{Ca}^{2+}$ accumulation in these cells, whereas activation of kainate receptors, in the presence of MK-801, did not induce any. The antagonists of the NMDA or kainate subtype of glutamate receptors, MK-801 and DNQX, respectively, eliminated the glutamate-induced ${ }^{45} \mathrm{Ca}^{2+}$ accumulation, indicating that both of these receptor subtypes are important for glutamate neuroexcitation. However, we found that kainate-induced ${ }^{45} \mathrm{Ca}^{2+}$ accumulation in the presence of MK-801, an NMDA receptor antagonist, was not significantly different from baseline. Thus, kainate receptors do not directly mediate calcium influx in this system but rather indirectly through membrane depolarization and removal of the magnesium block from the NMDA receptors (Mayer et al.,
1984; Nowak et al., 1984), therefore activating these receptors. The finding that NMDA induced less ${ }^{45} \mathrm{Ca}^{2+}$ accumulation than glutamate suggests calcium entry through other calcium channels than NMDA receptor-mediated channels. Stimulation of glutamate receptors also activates the voltage-dependent calcium channels through membrane depolarization. This was shown by adding $5 \mu \mathrm{M}$ of $\omega$-conotoxin GVIA, a blocker of the N-type calcium channels, which significantly reduced the glutamateinduced ${ }^{45} \mathrm{Ca}^{2+}$ accumulation (Fig. 2). From these findings, we have concluded that the NMDA receptors are the main route of calcium entry into cerebellar granule cells and that the nonNMDA and voltage-dependent calcium channels are equally important during glutamate stimulation.

\section{Taurine and heterologous serum downregulate glutamate-induced calcium accumulation}

It has been established in recent years that intracellular calcium concentrations determine, in part, neuronal cell survival and function. Therefore, the mechanism by which taurine prevents excitotoxic cell death may function through regulating calcium influx into neuronal cells during glutamate receptor-mediated depolarization. As shown in Figure 3, glutamate induced a significant increase in ${ }^{45} \mathrm{Ca}^{2+}$ accumulation into cerebellar granule cells grown in serum-free medium. Such an increase was significantly reduced when cells were pretreated for $24 \mathrm{hr}$ with $10 \mathrm{~mm}$ taurine. Taurine alone had no effect on calcium accumulation. Similarly, glutamate-induced ${ }^{45} \mathrm{Ca}^{2+}$ accumulation was significantly reduced when $2 \%$ HS was added to the culture medium (plus $13 \% \mathrm{~N}-2$ supplement), and it was completely abolished when the culture medium was supplemented with $10 \%$ HS and $5 \% \mathrm{~N}-2$. These data further indicate that the composition of the growth medium significantly controls the cellular response to external stimuli and further suggest that horse serum contains a factor(s) that suppresses the glutamate-induced calcium accumulation.

\section{Taurine modulation of glutamate-induced calcium accumulation is time-dependent}

Time course studies of glutamate-induced ${ }^{45} \mathrm{Ca}^{2+}$ accumulation showed that depolarization with $1 \mathrm{~mm}$ glutamate caused a significant increase in intracellular ${ }^{45} \mathrm{Ca}^{2+}$ after a 2 min stimulation. The linear increase in ${ }^{45} \mathrm{Ca}^{2+}$ accumulation continued over time up to $30 \mathrm{~min}$ (Fig. $4 A, B$ ).

To determine the effectiveness of taurine, we measured ${ }^{45} \mathrm{Ca}^{2+}$ accumulation in cultures treated with taurine and glutamate simultaneously (Fig. 4A) and in cultures pretreated with taurine for $24 \mathrm{hr}$ before the addition of glutamate (Fig. 4B). At each time point examined, taurine pretreatment significantly reduced glutamate-induced ${ }^{45} \mathrm{Ca}^{2+}$ accumulation starting 2 min after glutamate stimulation (Fig. 4B). However, when taurine and glutamate were added simultaneously to the cultures, taurine did not affect the glutamate-induced ${ }^{45} \mathrm{Ca}^{2+}$ accumulation for $20 \mathrm{~min}$ (Fig. 4A). After $20 \mathrm{~min}$, taurine did reduce intracellular ${ }^{45} \mathrm{Ca}^{2+}$ content significantly (Fig. $4 A$ ). These results indicate that the modulation of ${ }^{45} \mathrm{Ca}^{2+}$ accumulation by taurine occurs in the cytoplasm and not at receptor levels. Because a minimum of 20 min were required for taurine to act (Fig. 4A), this would be consistent with a mechanism of transporter-mediated taurine uptake rather then an interaction with cell surface receptors. 

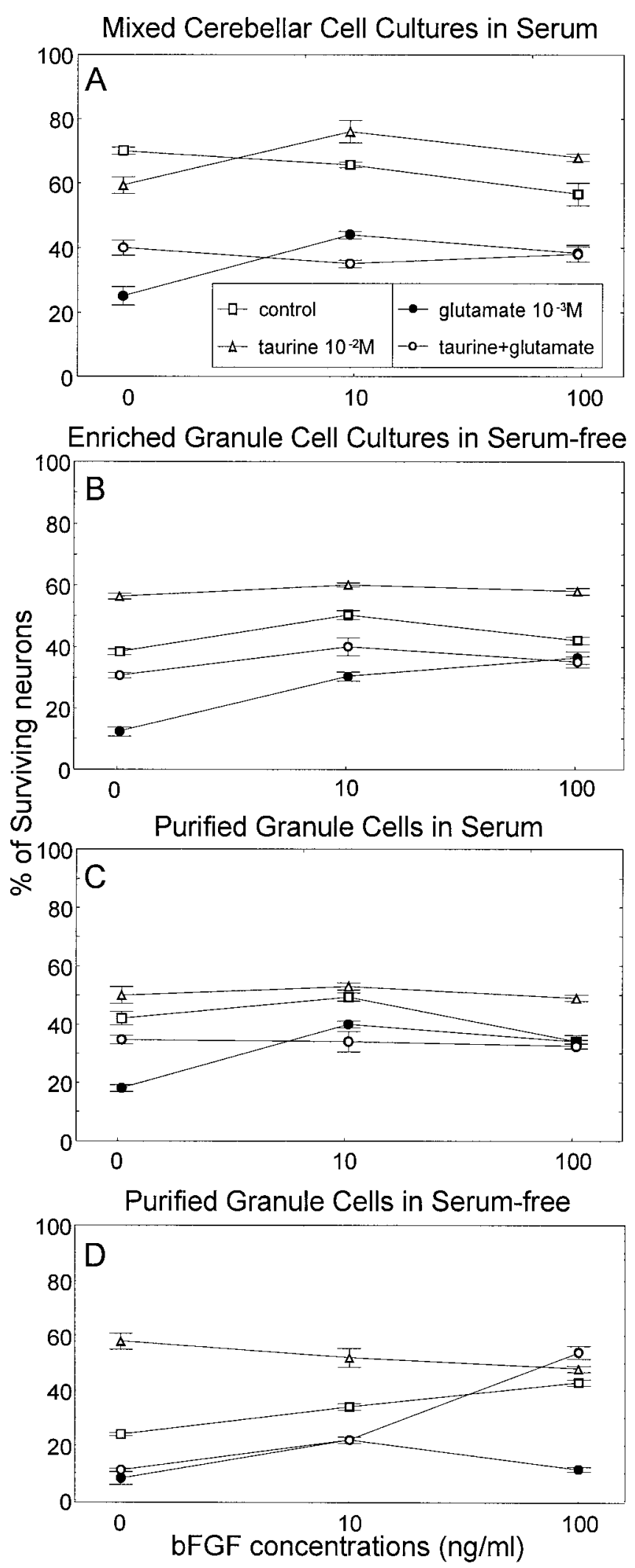

Figure 1. Effects of bFGF and taurine on glutamate-induced excitotoxicity. The survival of cerebellar granule neurons, isolated form early postnatal $\mathrm{C} 57 \mathrm{Bl} / \mathrm{J}$ mice (postnatal days $6-8$ ), was determined in vitro as a function of bFGF $(0.1-100 \mathrm{ng} / \mathrm{ml})$, taurine $(10 \mathrm{~mm})$, and glutamate $(1 \mathrm{~nm})$. Four conditions were compared: $A$, mixed cerebellar cells in MEM containing $10 \%$ HS and $5 \%$ FCS; $B$, enriched granule cells (5\% glia and

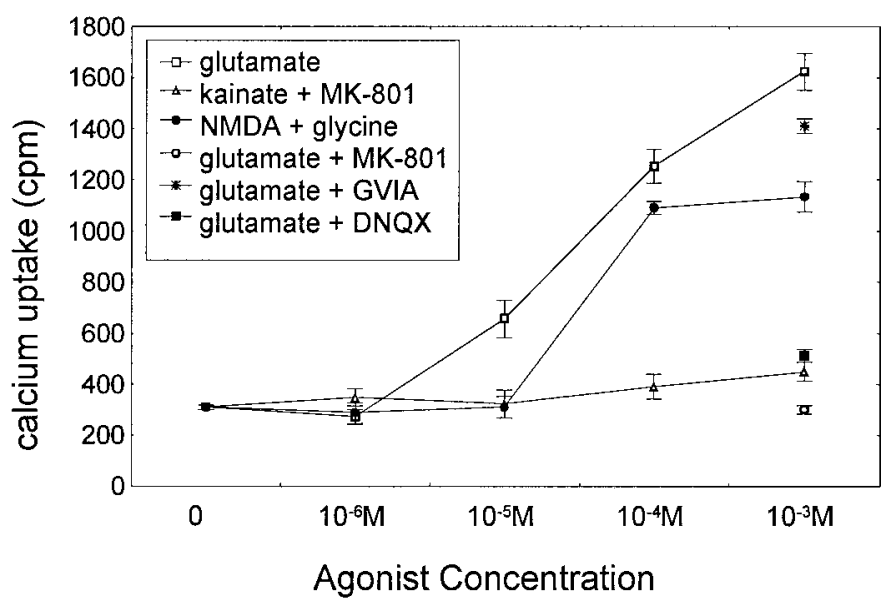

Figure 2. Calcium accumulation as a function of glutamate receptor activation. Cells were depolarized with various concentrations of glutamate, NMDA plus glycine $(10 \mu \mathrm{M})$, and kainate plus MK-801 $(10 \mu \mathrm{M})$ as indicated. ${ }^{45} \mathrm{Ca}^{2+}$ accumulation was determined 15 min after depolarization. Each data point represents mean \pm SEM of three experiments. ANOVA showed significant main effect of agonists $\left(F_{(2,30)}=85.30 ; p<\right.$ $0.0001)$ and concentrations $\left(F_{(4,30)}=121.91 ; p<0.0001\right)$. The interaction was also significant $\left(F_{(8,30)}=25.32 ; p<0.0001\right)$. Post hoc tests indicated that 10,100 , and $1000 \mu \mathrm{M}$ glutamate caused a significant increase in ${ }^{45} \mathrm{Ca}^{2+}$ accumulation above control levels $(p<0.001)$, whereas 100 and $1000 \mu \mathrm{M}$ NMDA were significantly different from controls $(p<0.001)$. Kainate in the presence of $10 \mu \mathrm{M}$ MK-801 did not induce a significant increase above baseline. Ten micromolar the kainate receptor antagonist DNQX or $10 \mu \mathrm{M}$ the NMDA receptor antagonist MK-801 completely blocked glutamate-induced ${ }^{45} \mathrm{Ca}^{2+}$ accumulation.

\section{bFGF and taurine protect against excitotoxicity through modulation of intracellular calcium}

bFGF, similar to taurine, modulated calcium influx in response to glutamate. As shown in Figure 5, bFGF at $10 \mathrm{ng} / \mathrm{ml}$ significantly reduced the glutamate-induced ${ }^{45} \mathrm{Ca}^{2+}$ accumulation, suggesting that bFGF, possibly through regulation of calcium uptake, protects neurons from glutamate excitotoxicity. On the other hand, $\mathrm{BDNF}$ at $10 \mathrm{ng} / \mathrm{ml}$ had no significant effect on glutamate-induced ${ }^{45} \mathrm{Ca}^{2+}$ accumulation (Fig. 5), although BDNF was neuroprotective (data not shown). This suggests that the neuroprotection of BDNF may be mediated through mechanisms different from

$\longleftarrow$

95\% neurons) in serum-free medium (MEM plus 15\% N-2 supplement); $C$, purified cerebellar neurons maintained in MEM with serum (10\% HS and $5 \% \mathrm{FCS}) ; D$, purified cerebellar neurons maintained in serum-free medium (MEM plus $15 \% \mathrm{~N}-2$ supplement). Cells were initially plated in serum-containing medium (MEM plus 10\% HS plus 5\% FCS). After 24 $\mathrm{hr}$, the culture medium was replaced with the growth medium as indicated. Cells were preincubated with bFGF and/or taurine for $24 \mathrm{hr}$ before glutamate. The number of living cells was determined 6-10 hr after glutamate addition. A three-way ANOVA showed a statistically significant interaction between NAAs $\times$ bFGF concentrations $\times$ culture condition $\left(F_{(18,96)}=19.24 ; p<0.0001\right)$. There was a significant main effect of NAAs $\left(F_{(3,96)}=612.45 ; p<0.0001\right)$, bFGF concentrations $\left(F_{(2,96)}=81.08 ; p<\right.$ $0.0001)$, and culture conditions $\left(F_{(3,96)}=208.97 ; p<0.0001\right)$. Post hoc tests showed that cell survival of controls in mixed cultures was significantly higher than controls in all other cultures $(p<0.001)$. Cell survival of controls of purified neurons in serum-free medium was significantly lower than that of controls from all other cultures $(p<0.001)$. Glutamate reduced cell viability in all culture conditions compared with the corresponding controls $(p<0.001)$. Under all four culture conditions (except in $D$ ), taurine alone or combined with different concentrations of bFGF significantly increased cell viability in glutamate-treated cultures $(p<$ $0.005)$. 


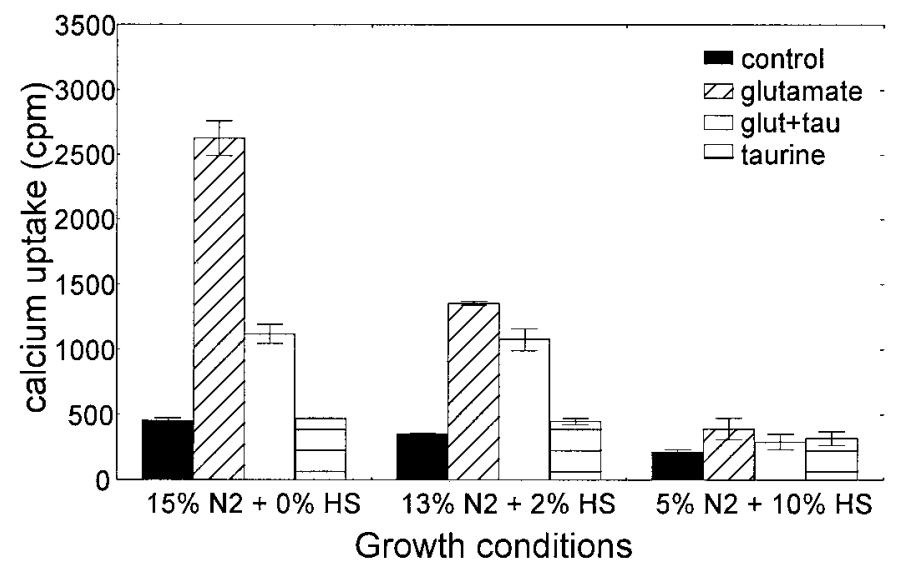

Figure 3. Taurine and horse serum downregulate glutamate-induced calcium accumulation. Taurine modulation of glutamate-induced ${ }^{45} \mathrm{Ca}^{2+}$ accumulation was analyzed in early postnatal cerebellar granule cells cultured in serum-free medium and supplemented with different concentrations of $\mathrm{HS}(0,2$, and $10 \%$, respectively). Cells were initially plated under serum conditions (10\% HS plus 5\% FCS). After $24 \mathrm{hr}$ in vitro, cultures were switched to serum-free medium $(15 \% \mathrm{~N}-2$ supplement). At 3 days in vitro, $0.25 \mathrm{ml}$ of culture medium was removed and replaced with $0.25 \mathrm{ml}$ of fresh medium supplemented with HS to give the desired final concentration $(0,2$, or $10 \%)$. Ten millimolar taurine was added at this time. Twenty-four hours later, ${ }^{45} \mathrm{Ca}^{2+}$ accumulation was measured after depolarization with $1 \mathrm{~mm}$ glutamate for $30 \mathrm{~min}$. Data represent mean \pm SEM from at least three separate experiments. A two-way ANOVA showed a statistically significant interaction between HS concentrations and NAA treatment $\left(F_{(6,24)}=65.82 ; p<0.0001\right)$. There was a significant main effect of HS concentrations $\left(F_{(2,24)}=200 ; p<0.0001\right)$ and NAA treatment $\left(F_{(3,24)}=200 ; p<0.0001\right)$. Post hoc tests showed that glutamate-induced ${ }^{45} \mathrm{Ca}^{2+}$ accumulation was significantly higher than control $(p<0.001)$ under 0 and $2 \%$, but not $10 \%$, HS.

those suggested for taurine and bFGF. The collaboration between BDNF and bFGF $(10 \mathrm{ng} / \mathrm{ml})$ also significantly reduced the glutamate-induced ${ }^{45} \mathrm{Ca}^{2+}$ accumulation to levels ranging between those of BDNF and bFGF (Fig. 5), indicating that BDNF can affect bFGF activity.

To characterize the role of taurine in the presence of BDNF and bFGF, glutamate-induced ${ }^{45} \mathrm{Ca}^{2+}$ accumulation was measured in cultures pretreated with these factors for $24 \mathrm{hr}$. As expected, ${ }^{45} \mathrm{Ca}^{2+}$ accumulation was significantly reduced when cultures were pretreated with taurine. The levels obtained were comparable with those obtained with bFGF (Fig. 5). Furthermore, taurine was more efficient in reducing the glutamateinduced ${ }^{45} \mathrm{Ca}^{2+}$ accumulation when cells were pretreated with either BDNF or bFGF $(10 \mathrm{ng} / \mathrm{ml})$. When cells were pretreated with all three factors, glutamate-induced ${ }^{45} \mathrm{Ca}^{2+}$ accumulation significantly exceeded the levels of mediation seen with taurine alone or in combination with either growth factor. However, the combination of BDNF and bFGF did not reduce ${ }^{45} \mathrm{Ca}^{2+}$ accumulation further in the presence of taurine, as could have been expected in view of BDNF and bFGF interactions (Fig. 5). Under nondepolarizing conditions, ${ }^{45} \mathrm{Ca}^{2+}$ accumulation in the presence of GFs and taurine was similar to that of untreated controls.

\section{Intracellular calcium is regulated differently by taurine and bFGF}

$\left[\mathrm{Ca}^{2+}\right]_{\mathrm{i}}$ was measured by fluorescence microscopy in cerebellar neurons with granule cell-like morphology after loading the cells with fluo-3. Approximately $95 \%$ of these cells responded to glutamate $(1 \mathrm{~mm})$ with a rapid increase in $\left[\mathrm{Ca}^{2+}\right]_{\mathrm{i}}$ (Fig. 6A). Basal $\left[\mathrm{Ca}^{2+}\right]_{\mathrm{i}}$ in these neurons was $\sim 200 \mathrm{~nm}$ but was increased
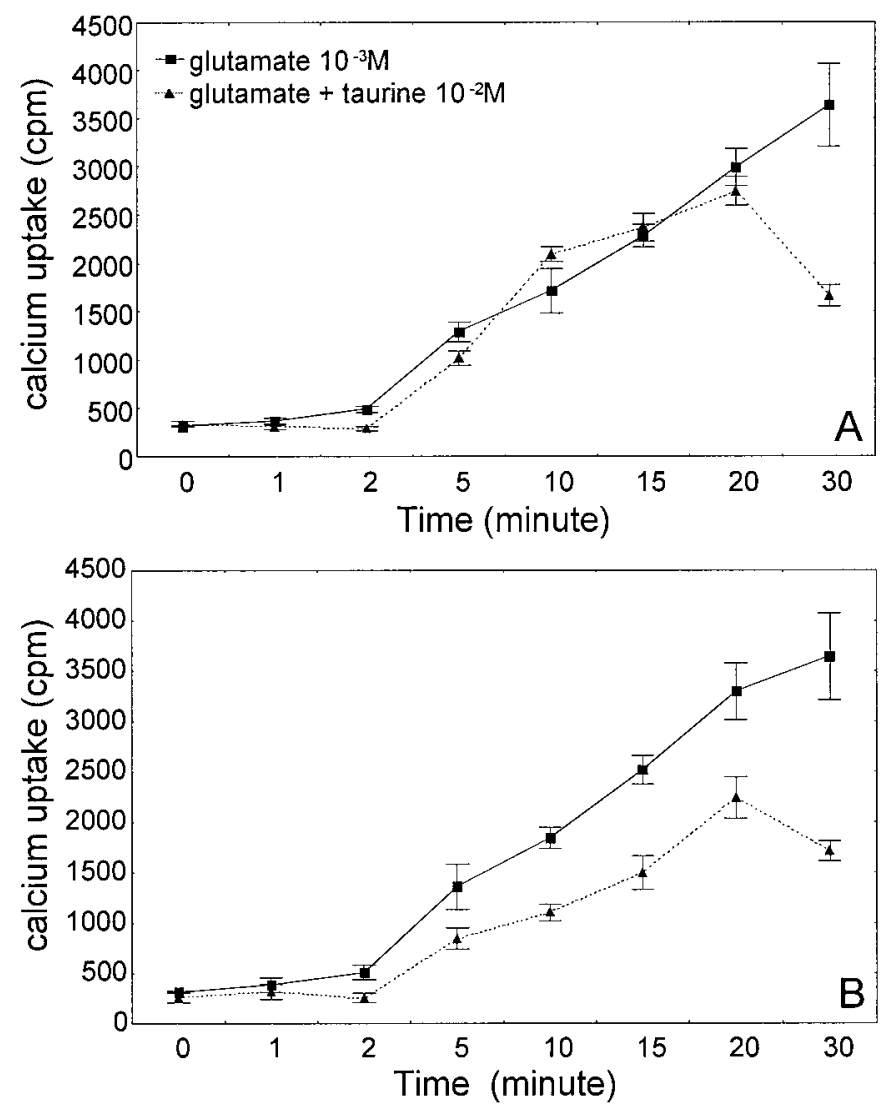

Figure 4. Time course accumulation of calcium under glutamate depolarization. $A$, Taurine was added simultaneously with glutamate. $B$, Cultures were pretreated with taurine $(10 \mathrm{~mm})$ for $24 \mathrm{hr}$ before addition glutamate $(1 \mathrm{mM})$. Each data point represents the mean \pm SEM of three separate experiments. A two-way ANOVA showed a statistically significant main effect of taurine treatment $\left(F_{(2,48)}=33.88 ; p<0.0001\right)$ and time of depolarization $\left(F_{(7,48)}=103.92 ; p<0.0001\right)$. The interaction between taurine and time was also significant $\left(F_{(14,48)}=5.53 ; p<0.0001\right)$. Post hoc tests indicated that glutamate caused a significant $(p<0.05)$ increase in ${ }^{45} \mathrm{Ca}^{2+}$ accumulation after $5 \mathrm{~min}$ and thereafter $(p<0.0001)$. $A$, Only at $30 \mathrm{~min}$ did taurine significantly $(p<0.001)$ reduce ${ }^{45} \mathrm{Ca}^{2+}$ accumulation. In $B$, taurine induced a significant $(p<0.05)$ reduction 15 min after depolarization.

sixfold after glutamate was added to the medium to reach levels of $\sim 1.2 \mu \mathrm{M}$ (Fig. $6 \mathrm{~A}$ ). In the presence of glutamate, most neurons showed a sustained increase in $\left[\mathrm{Ca}^{2+}\right]_{\mathrm{i}}$ with no recovery to the basal levels over a period of $20 \mathrm{~min}$ (Fig. 6A). However, in cultures pretreated for $24 \mathrm{hr}$ with $10 \mathrm{~mm}$ taurine, glutamate induced a rapid increase of $\left[\mathrm{Ca}^{2+}\right]_{\mathrm{i}}$ (Fig. $6 \mathrm{~B}$ ), which returned to basal levels $\sim 10$ min later. In contrast, pretreatment with bFGF $(10 \mathrm{ng} / \mathrm{ml})$ resulted in significantly reduced but constant $\left[\mathrm{Ca}^{2+}\right]_{\mathrm{i}}$ after adding glutamate (less than twofold increase), with no recovery to basal levels over $23 \mathrm{~min}$ (Fig. 6C). As shown in Figure $6 \mathrm{D}$, photobleaching of intracellular fluo-3 signals did not interfere with the $\left[\mathrm{Ca}^{2+}\right]_{i}$ determination. $\left[\mathrm{Ca}^{2+}\right]_{i}$ in cells did not change significantly over a period of $20 \mathrm{~min}$ under the same image-acquisition settings.

\section{Growth factors and taurine enhance the mitochondrial function}

Neuronal development and maintenance of function depend on cellular energy. Energy metabolism is recognized as one of the fundamental factors that control the required balance between 


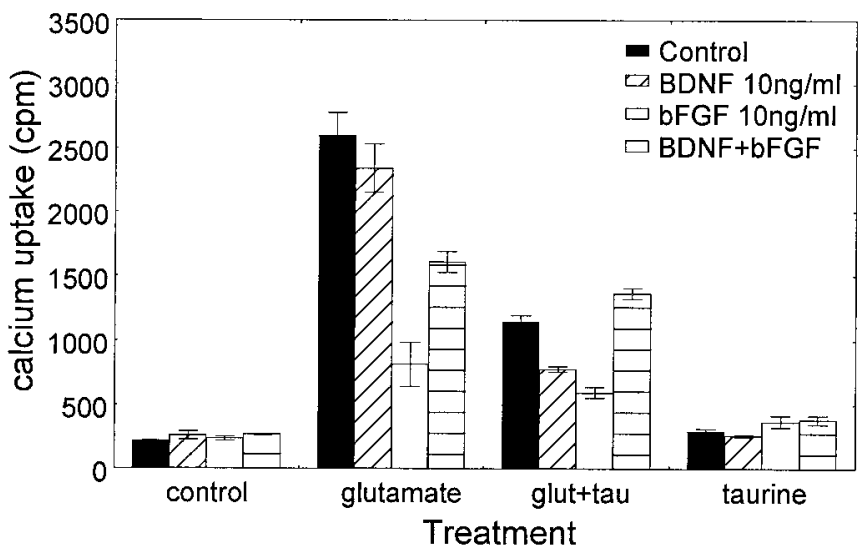

Figure 5. Interaction of GFs and taurine during calcium uptake modulation. Cells were pretreated with $\mathrm{bFGF}$ and BDNF $(10 \mathrm{ng} / \mathrm{ml})$ and with taurine $(10 \mathrm{~mm})$ or a combination thereof for $24 \mathrm{hr}$. Glutamate was added for $30 \mathrm{~min}$, and ${ }^{45} \mathrm{Ca}^{2+}$ and accumulation were measured as described. Data represent mean \pm SEM from three separate experiments. The two-way ANOVA showed a statistically significant interaction between growth factors and NAAs $\left(F_{(9,32)}=25.10 ; p<0.0001\right)$. There was also a significant main effect of growth factors $\left(F_{(3,32)}=32.09 ; p<0.0001\right)$ and NAAs $\left(F_{(3,32)}=304.52 ; p<0.0001\right)$. Post hoc tests indicated that glutamate significantly increased intracellular ${ }^{45} \mathrm{Ca}^{2+}$ under all conditions examined $(p<0.005)$. bFGF or bFGF and BDNF caused a significant reduction in glutamate-induced ${ }^{45} \mathrm{Ca}^{2+}$ accumulation $(p<0.001)$. Taurine alone or combined with GFs significantly reduced ${ }^{45} \mathrm{Ca}^{2+}$ accumulation $(p<0.0005)$ in the presence of glutamate.

maintenance of neuronal structures and their function during development and throughout adult life (Beal, 1995; Hoyer, 1993).We and others recently demonstrated that depleted cellular energy levels caused by malfunction of the MtECG increased the vulnerability of cultured neuronal cells toward excitotoxins and neurotoxins, leading to neuronal malfunction and subsequently to cell death (Dykens, 1994; Budd and Nicholls, 1996; Trenkner et al., 1996; El Idrissi et al., 1998). In this study, we examined the potential protective effects of growth factors and taurine on the mitochondrial function under excitotoxic conditions.

Treatment of cerebellar granule cells with BDNF or bFGF significantly increased the MtECG activity compared with controls (Fig. 7). Similarly, the addition of taurine (10 mM) alone or in combination with BDNF and bFGF resulted in a significant increase of rhodamine uptake over untreated controls. Thus, taurine, BDNF, and bFGF may provide trophic support to cerebellar granule cells, as indicated by enhanced MtECG activity. Whereas taurine and GFs increased the mitochondrial activity, glutamate had opposite effects (Fig. 7). However, pretreatment with taurine and bFGF together before glutamate depolarization restored the MtECG to levels comparable with controls (Fig. 7). This increase in mitochondrial function with both taurine and bFGF under depolarizing condition may well be the result of their ability to regulate the intracellular calcium homeostasis. Therefore, different mechanisms and combinations of those analyzed here could lead to trophic support through modulating the activity of MtECG.

\section{Taurine specificity}

The taurine analogs $\beta$-alanine and guanidinoethan sulfonate (GES) have been used as taurine-specific uptake blockers or competitors (Quesada et al., 1984; Moran and Pasantes-Morales, 1991). We have used both analogs in most of the experiments described here to demonstrate taurine-specific involvement.
However, unexpectedly, $\beta$-alanine in equal concentrations to taurine (10 mM) had no effect on ${ }^{45} \mathrm{Ca}^{2+}$ accumulation (Fig. 8), nor did it block the role of taurine as calcium modulator during prevention of excitotoxic cell death. Thus, $\beta$-alanine, although similar in structure to taurine, does not inhibit the modulatory functions of taurine. Similar results were obtained with GES, a taurine analog. These data suggest that taurine plays an active role in these regulatory mechanisms and that $\beta$-alanine and GES may not be used as specific taurine uptake blockers under these experimental conditions.

\section{DISCUSSION}

Because one of the essential mechanisms in neuronal development is the regulation and maintenance of calcium homeostasis (Mattson, 1988, 1992; Mattson and Cheng, 1993), we attempted to determine how and whether neuroactive amino acids (NAAs) and GFs, known to mediate survival and function of cerebellar granule cells, interact in the regulation of calcium homeostasis during crucial steps in early postnatal cerebellar development and during excitotoxic conditions. Calcium ions are ubiquitous intracellular second messengers and act as key regulators of numerous cellular functions. Therefore, neurons must tightly regulate the concentrations of free cytoplasmic calcium to survive and function. Deregulation of intracellular calcium homeostasis causes numerous brain pathologies, including glutamate excitotoxicity (Dykens et al., 1987; Choi, 1987, 1988; Mattson and Cheng, 1993; Mattson et al., 1993; Eimerl and Schramm, 1995).

We have used taurine and glutamate as representatives of neuroactive amino acids, and bFGF and BDNF as examples of two distinct growth factor families. Because all of these molecules are present at a given time in the intracellular and extracellular environment, we have tried to characterize their interaction and questioned whether these molecules induce the same cellular regulatory systems and could substitute for each other, whether the regulation of calcium influx is synergistic or additive, and whether these mechanisms are complementary depending on their concentration and availability.

It is well established that the viability of neurons is greatly affected by their extracellular environment; e.g., more neurons survived in the presence of serum and astroglial cells (Fig. 1A). Additions of factors with known neurotrophic support on cerebellar granule cells (bFGF and taurine) did not further improve cell survival beyond untreated controls, suggesting that optimal conditions were reached. In particular, both horse serum and astroglial cells had a significant influence on cell survival, as was shown by others as well as in this study (Trenkner et al., 1984; Hatten et al., 1988; Trenkner, 1990; Casper and Blum, 1995; Wood et al., 1997). When glial cells were removed from these cultures, the viability of purified cerebellar granule neurons was significantly reduced, providing evidence that serum and astroglial cells have trophic and protective effects.

Figure 1 demonstrates clearly the protective effects of the particular media under excitotoxic stress. Serum-containing cultures with astrocytes provided the most protection, possibly because trophic factors in serum and released glial factors protected to a maximum. Alternatively, in mixed cultures, glutamate may be removed by high-affinity uptake transporters (Fonnum, 1984; Rosenberg and Aizenman, 1989; Rosenberg, 1991), as Casper and Blum (1995) have shown. They determined that, in mixed cultures of dopaminergic neurons, glutamate uptake was significantly increased by bFGF through its mitogenic effect on astro- 

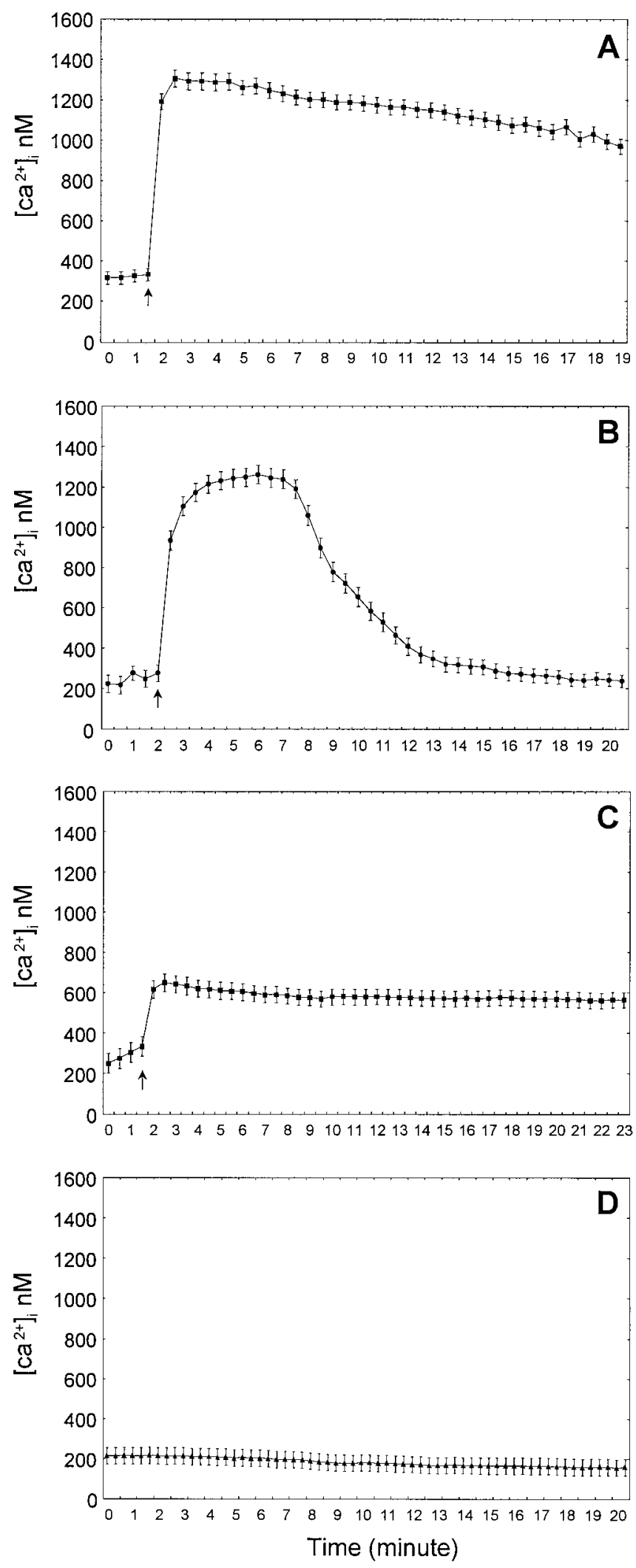

Figure 6. Regulation of $\left[\mathrm{Ca}^{2+}\right]_{\mathrm{i}}$ by taurine and bFGF. $\left[\mathrm{Ca}^{2+}\right]_{\mathrm{i}}$ was determined by confocal microscopy in cells attached to coverslips and loaded with $5 \mu \mathrm{M}$ fluo-3. Images were acquired at $30 \mathrm{sec}$ intervals. $A-D$ show one set of data of one representative experiment. Each determination was repeated at least twice or more. Although the measurements vary from one experiment to another, the outcome was identical. Each point

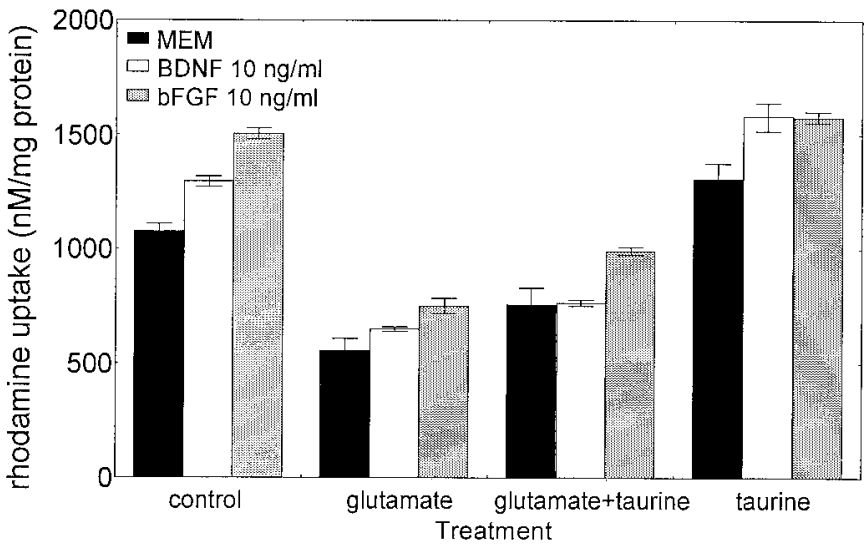

Figure 7. Combination of taurine and bFGF counteracted the glutamate-induced decrease in MtECG. Cells were treated with BDNF $(10 \mathrm{ng} / \mathrm{ml})$, bFGF $(10 \mathrm{ng} / \mathrm{ml})$, or taurine $(10 \mathrm{~mm})$ as indicated. Twentyfour hours later, cells were depolarized with $100 \mu \mathrm{M}$ glutamate for $30 \mathrm{~min}$. Data represent mean \pm SEM of three experiments. A two-way ANOVA involving the interactions between NAAs and GFs was significant $\left(F_{(6,24)}=2.65 ; p<0.05\right)$. The main effect of NAAs was highly significant $\left(F_{(3,24)}=155.9 ; p<0.0001\right)$. The effect of GFs was also significant $\left(F_{(2,24)}=30.35 ; p<0.0001\right)$. Post hoc tests indicated that BDNF and bFGF induced significantly $(p<0.005)$ increased rhodamine uptake. Glutamate significantly $(p<0.01)$ reduced rhodamine uptake but not in cultures pretreated with taurine and bFGF compared with untreated controls.

cytes, reducing therefore its extracellular concentration and hence the excitotoxicity.

Our results suggest that neuroprotection is controlled by other mechanisms in addition to those involving transport and elimination of glutamate from the medium. These include regulation of intracellular calcium and neuronal energy metabolism. Support for this alternative mechanism comes from experiments in which the glutamate-induced calcium uptake was assessed in the presence of growth factors (Mattson et al., 1993; Cheng et al., 1995), showing quantitative correlations between excitotoxicity and total glutamate receptor-mediated calcium accumulation in neurons (Choi, 1988; Hartley et al., 1993; Eimerl and Schramm, 1994). Furthermore, we showed that glutamate-induced intracellular ${ }^{45} \mathrm{Ca}^{2+}$ accumulation was time- and dose-dependent (Figs. 2, 4).

Although both taurine and bFGF regulated glutamate-induced ${ }^{45} \mathrm{Ca}^{2+}$ accumulation (Fig. 5), they seem to act through different mechanisms (Fig. 6B,C). These differences became obvious through the two ways we determined $\left[\mathrm{Ca}^{2+}\right]_{\mathrm{i}}$. Although the content of ${ }^{45} \mathrm{Ca}^{2+}$ in cells determines the amount of ${ }^{45} \mathrm{Ca}^{2+}$ that has accumulated in these cells over time, this method does not differentiate between the total concentration, additional calcium uptake, extrusion, sequestration, or buffering. Confocal microscopy, on the other hand, allowed us to measure the total amount, as well as the increase of cytoplasmic free calcium over time (Fig. $6 B, C)$. We used fluo-3 as calcium indicator and not fura-2 or

$\leftarrow$

represents the mean $\pm \mathrm{SEM}$ of $\left[\mathrm{Ca}^{2+}\right]_{\mathrm{i}}$ determined as indicated in Materials and Methods. $A$, Glutamate $(1 \mathrm{~mm})$ was applied directly to the recording chamber as indicated by the arrow and was present throughout the recording period ( $n=73$ cells). $B$, Cells were pretreated with $10 \mathrm{~mm}$ taurine for $24 \mathrm{hr}$ before glutamate addition $(n=82)$. Taurine was also present during the recording. $C$, Cultures were pretreated for $24 \mathrm{hr}$ with $10 \mathrm{ng} / \mathrm{ml} \mathrm{bFGF}(n=65) . D$, The extent of photobleaching of the signal intensities. The software and microscope settings were maintained the same as for $A-C$, but images were acquired at $20 \mathrm{sec}$ intervals $(n=57)$. 


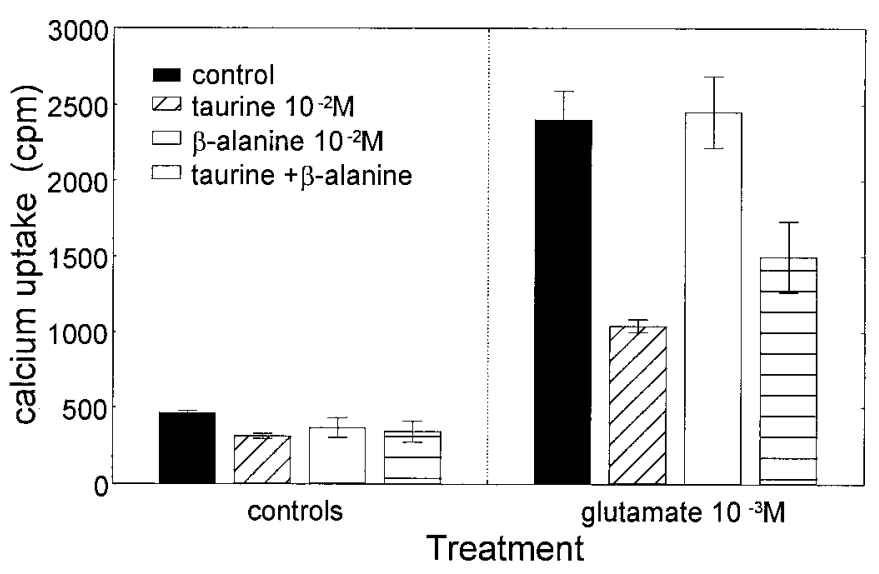

Figure 8. Effects of taurine and $\beta$-alanine on glutamate-induced calcium accumulation. Cells were pretreated with taurine, $\beta$-alanine, or a combination of the two at $10 \mathrm{~mm} .{ }^{45} \mathrm{Ca}^{2+}$ accumulation was measured $30 \mathrm{~min}$ after depolarization with glutamate. Data represent mean \pm SEM from three separate experiments. A two-way ANOVA showed a statistically significant interaction between glutamate and treatment with taurine and $\beta$-alanine $\left(F_{(3,16)}=10.48 ; p<0.0005\right)$. There was a significant main effect of glutamate $\left(F_{(1,16)}=221.88 ; p<0.0001\right)$ and taurine and/or $\beta$-alanine $\left(F_{(3,16)}=14.16 ; p<0.0001\right)$. Post hoc tests indicated that glutamate induced a significant $(p<0.001)$ increase in ${ }^{45} \mathrm{Ca}^{2+}$ accumulation, which was significantly $(p<0.001)$ reduced by taurine and by taurine and $\beta$-alanine $(p<0.001)$. $\beta$-Alanine had no significant effect on glutamateinduced ${ }^{45} \mathrm{Ca}^{2+}$ accumulation.

other calcium binding dyes because fuo-3 did not bleach over the period of observation $(30 \mathrm{~min})$. The importance of this fact was investigated by others (Becker and Fay, 1987), as well as in this study (Fig. 6D), and resulted in a semiquantitative determination of $\left[\mathrm{Ca}^{2+}\right]_{\mathrm{i}}$. Furthermore, the combination of these two methods provided a better understanding of calcium kinetics after glutamate depolarization and led us to postulate two regulatory mechanisms mediated by either taurine or bFGF.

As shown by Cheng et al. (1995), bFGF increases the expression levels of the GluR1 subunit of the AMPA receptor and suppresses the expression of a $71 \mathrm{kDa}$ NMDA receptor protein in hippocampal (Mattson et al., 1993) and cerebellar neurons (Brandoli et al., 1998). If this is the case, suppression of the number of NMDA receptors would explain our results that bFGF reduces $\left[\mathrm{Ca}^{2+}\right]_{\mathrm{i}}$ in the presence of glutamate, thus reducing neuronal vulnerability to calcium-mediated glutamate excitotoxicity.

Taurine, on the other hand, did not affect the magnitude of $\left[\mathrm{Ca}^{2+}\right]_{\mathrm{i}}$ after glutamate stimulation but rather downregulated $\left[\mathrm{Ca}^{2+}\right]_{\mathrm{i}}$ to basal levels $\sim 10 \mathrm{~min}$ after glutamate addition. These increases were transient, and $\left[\mathrm{Ca}^{2+}\right]_{\mathrm{i}}$ recovered to basal levels in minutes (Fig. 6B), an effect not seen with glutamate alone (Fig. $6 A$ ) or in the presence of bFGF (Fig. $6 C$ ). The full extent of how taurine restores the $\left[\mathrm{Ca}^{2+}\right]_{\mathrm{i}}$ after glutamate stimulation is not yet known. However, our results suggest that taurine does not affect the glutamate receptor-mediated calcium uptake directly but rather activates mechanisms inside the cell that reduce or redistribute cytoplasmic free calcium into different pools by extrusion, sequestration, or even buffering. We are presently addressing these questions.

Several mechanisms have been proposed to explain the neuroprotective role of taurine. Taurine is present in neurons and astroglial cells in multiple areas of the brain (Palkovits et al., 1986; Huxtable, 1992; Sturman, 1993). Moreover, it was shown that taurine is freely exchanged between these cells. We and others have suggested that taurine balances glutamate activity, particularly under excitotoxic conditions (Trenkner, 1990; Trenkner et al., 1996). The release and immediate uptake of taurine from neurons and glial cells has been associated with this neuroprotective effect (Trenkner, 1990; Bianchi et al., 1996; Trenkner et al., 1996; Katoh et al., 1997; Saransaari and Oja, 1997; Segovia et al., 1997). Furthermore, increasing the concentration of extracellular glutamate by infusion of selective inhibitors of the highaffinity glutamate uptake correlated with increasing concentrations of extracellular taurine. This increase was blocked by NMDA and AMPA-kainate receptor antagonists (Segovia et al., 1997). Taking these results together, the glutamate-induced taurine release might be neuroprotective. Yet another mechanism has been proposed involving taurine as an inhibitor of depolarization through increasing membrane chloride conductance via the activation of GABA and glycine receptors (Quinn and Miller, 1992). We have examined the possibility as to whether the ability of taurine to interact with GABA or glycine receptors had functional consequences (El Idrissi et al., 1998; Trenkner et al., 1998), but we were unable to detect any effect of GABA or glycine on the inhibition of ${ }^{45} \mathrm{Ca}^{2+}$ accumulation by taurine. However, we found that low concentrations of glycine $(10 \mu \mathrm{M})$ enhanced NMDA receptor activities, as described by Johnson and Asher (1987), in the absence of additional taurine. Recent electrophysiological studies of neocortical cultures have shown that taurine activates glycine receptors directly (Flint et al., 1998). In our culture system, however, taurine did not interact with either the glycine receptors as demonstrated by insensitivity to strychnine, a glycine receptor antagonist, or the glycine binding site of the NMDA receptor, as shown by the fact that taurine actions required pretreatment of the cells with taurine; however, glycine acted immediately (data not shown).

MtECG plays a pivotal role in controlling the maintenance of neuronal structures and their function throughout life (Mattson et al., 1993; Trenkner et al., 1994; Beal, 1995; Budd et al., 1997); the depletion of cellular energy, caused by malfunction of the MtECG, increased the vulnerability toward excitotoxins leading to neuronal cell death (Budd and Nicholls, 1995, 1996; El Idrissi et al., 1996; Trenkner et al., 1996). We have shown here that taurine $(10 \mathrm{~mm})$ in vitro alone or in combination with bFGF or BDNF facilitated an increase in mitochondrial activity as measured by an increase in rhodamine 123 uptake (Fig. 7). Furthermore, the selective collaboration of taurine and bFGF restored the MtECG after glutamate stimulation, possibly as a result of calcium regulation.

Although the mechanism(s) of the action of taurine is not fully understood, taurine plays a significant role in the regulation of calcium-mediated glutamate-induced signaling events. In particular, taurine has opposing effects to those of glutamate, modulated by the interaction with growth factors.

In conclusion, GFs and NAAs interact through modulation of calcium homeostasis after glutamate depolarization. Some of these factors induce the same regulatory mechanisms and appear to support each other. These findings further suggest that neuronal cells use alternative pathways to regulate and maintain their function. These pathways are accessible to cells depending on their developmental stages, the availability of these factors, and neuronal energy levels. We conclude that, under conditions in which more than one factor is present, as is likely in vivo, these factors differentially regulate the functions of each other to promote an optimal environment for cell survival and function. 


\section{REFERENCES}

Barbacid M (1994) The trk family of neurotrophin receptors. J Neurobiol 25:1386-1403.

Barde Y-A (1989) Trophic factors and neuronal survival. Neuron 2:1525-1534.

Beal MF (1995) Aging, energy, and oxidative stress in neurodegenerative diseases. Ann Neurol 18:357-366.

Beal MF, Hyman BT, Koroshetz W (1993) Do defects in mitochondrial energy metabolism underlie the pathology of neurodegenerative diseases ? Trends Neurosci 16:125-131.

Becker PL, Fay FS (1987) Photobleaching of fura-2 and its effect on determination of calcium concentrations. Am J Physiol 253:C613-C618.

Bianchi LM, Conover JC, Fritzsch B, DeChiara T, Lindsay RM, Yancopoulos GD (1996) Degeneration of vestibular neurons in late embryogenesis of both heterozygous BDNF null mutant mice. Development 122:1965-1973.

Bothwell M (1996) p $75^{\mathrm{NTR}}$ : a receptor after all. Science 272:506-507.

Bottenstein JE, Skaper SD, Varon SS, Sato GH (1980) Selective survival of neurons from chick embryo sensory ganglionic dissociates utilizing serum-free supplemented medium. Exp Cell Res 125:183-190.

Bradford MM (1976) A rapid and sensitive method for the quantitation of microgram quantities of protein utilizing the principle of protein-dye binding. Anal Biochem 72:248-254.

Brandoli C, Sanna A, DeBernardi MA, Follesa P, Brooker G, Mocchetti I (1998) Brain-derived neurotrophic factor and basic fibroblast growth factor down regulate NMDA receptor function in cerebellar granule cells. J Neurosci 18:7953-7961.

Budd SL, Nicholls DG (1995) A reevaluation of the role of mitochondria in neuronal $\mathrm{Ca}^{2+}$ homeostasis. J Neurochem 66:403-411.

Budd SL, Nicholls DG (1996) Mitochondria, calcium regulation, and acute glutamate excitotoxicity in cultured cerebellar granule cells. J Neurochem 67:2282-2291.

Budd SL, Castilho RF, Nicholls DG (1997) Mitochondrial membrane potential and hydroethidine-monitored superoxide generation in cultured cerebellar granule cells. FEBS Lett 415:21-24.

Casper D, Blum M (1995) Epidermal growth factor and basic fibroblast growth factor protect dopaminergic neurons from glutamate toxicity in culture. J Neurochem 65:1016-1026.

Chao MV (1992) Neurotrophin receptors: a window into neuronal differentiation. Neuron 9:583-593.

Chen LB (1989) Fluorescent labeling of mitochondria. Methods Cell Biol 29:103-123.

Cheng B, Furukawa K, O'Keefe JA, Goodman Y, Kihiko M, Fabian T, Mattson MP (1995) Basic fibroblast growth factor selectively increases AMPA-receptor subunit GluR1 protein level and differentially modulates $\mathrm{Ca}^{2+}$ responses to AMPA and NMDA in hippocampal neurons. Neurochemistry 65:2525-2536.

Choi DW (1987) Ionic dependence of glutamate neurotoxicity. J Neurosci 7:369-379.

Choi DW (1988) Glutamate neurotoxicity and diseases of the nervous system. Neuron 1:623-634.

Choi DW (1990) The role of glutamate neurotoxicity in hypoxicischemic neuronal death. Annu Rev Neurosci 13:171-182.

Dykens JA (1994) Isolated cerebral and cerebellar mitochondria produce free radicals when exposed to elevated $\mathrm{Ca}^{2+}$ and $\mathrm{Na}^{+}$: implication for neurodegeneration. J Neurochem 63:584-591.

Dykens JA, Stern A, Trenkner E (1987) Mechanism of kainate toxicity to cerebellar neurons in vitro is analogous to reperfusion tissue injury. J Neurochem 49:1222-1228.

Eimerl S, Schramm M (1994) The quantity of calcium that appears to induce neuronal death. J Neurochem 62:1223-1226.

Eimerl S, Schramm M (1995) Resuscitation of brain neurons in the presence of $\mathrm{Ca}^{2+}$ after toxic NMDA-receptor activity. J Neurochem 65:739-744.

El Idrissi A, Harris A, Trenkner E (1996) Neurotrophins, neuro-active amino acids and the mitochondrial respiratory chain together maintain neuronal survival and function. Soc Neurosci Abstr 22:770.

El Idrissi A, Harris C, Trenkner E (1998) Taurine modulates glutamateand growth factors-mediated signaling mechanisms. Adv Exp Med Biol 442:385-396.

Favaron M, Manev H, Alho H, Bertolino M, Ferret B, Guidotti A, Costa E (1988) Gangliosides prevent glutamate and kainate neurotoxicity in primary neuronal cultures of neonatal rat cerebellum and cortex. Proc Natl Acad Sci USA 85:7351-7355.
Flint AC, Liu X, Kriegstein AR (1998) Nonsynaptic glycine receptor activation during early neocortical development. Neuron 20:43-53.

Fonnum F (1984) Glutamate: a neurotransmitter in mammalian brain. J Neurochem 42:1-11.

Green DR, Reed JC (1998) Mitochondria and apoptosis. Science 281:1309-1312.

Greene LA, Kaplan DR (1995) Early events in neurotrophin signaling via Trk and p75 receptors. Curr Top Neurobiol 5:579-587.

Grynkiewicz G, Peonie M, Tsien RY (1985) A new generation of calcium indicators with greatly improved fluorescence properties. J Biol Chem 260:3440-3450.

Gunter TE, Gunter KK, Sheu SS, Gavin CE (1994) Mitochondrial calcium transport: physiological and pathological relevance. Am J Physiol 267:313-339.

Hartley DM, Kurth MC, Bjerkness L, Weiss JH, Choi DW (1993) Glutamate receptor-induced ${ }^{45} \mathrm{Ca}^{2+}$ accumulation in cortical cell culture correlates with subsequent neuronal degeneration. J Neurosci 13:1993-2000.

Hatten ME (1985) Neuronal regulation of astroglial morphology and proliferation in vitro. J Cell Biol 100:384-396.

Hatten ME, Lynch M, Rydel RE, Sanchez J, Joseph-Silverstein J, Moscatelli D, Rifkin DB (1988) In vitro neurite extension by granule neurons is dependent upon astroglial-derived fibroblast growth factor. Dev Biol 125:280-289.

Hertz L, Drejer J, Schousboe A (1988) Energy metabolism in glutamatergic neurons, GABAergic neurons and astrocytes in primary cultures. Neurochem Res 13:605-610.

Hoyer S (1993) Brain oxidative energy and related metabolism, neuronal stress, and Alzheimer's disease: a speculative synthesis. J Geriatr Psychiatry Neurol 1:3-13.

Huxtable RJ (1992) The physiological actions of taurine. Physiol Rev 72:101-163.

Jaffe DB, Brown TH (1994) Metabotropic glutamate receptor activation induces calcium waves within hippocampal dendrites. J Neurophysiol 72:471-474.

Johnson JW, Ascher P (1987) Glycine potentiates the NMDA response in cultured mouse brain neurons. Nature 325:529-531.

Kao JP (1994) Practical aspects of measuring $\left[\mathrm{Ca}^{2+}\right]$ with fluorescent indicators. Methods Cell Biol 40:155-181.

Kater SB, Mattson MP, Cohan C, Connor J (1988) Calcium regulation of the neuronal growth cone. Trends Neurosci 11:315-321.

Katoh H, Sima K, Nawashiro H, Wada K, Chigasaki H (1997) The effect of MK-801 on extracellular neuroactive amino acids in hippocampus after closed head injury followed by hypoxia in rats. Brain Res 758:153-162.

Lin K, Sadée W, Quillan JM (1999) Rapid measurements of intracellular calcium using a fluorescence plate reader. Biotechniques 26:318-326.

Liu X, Kim CN, Yang J, Jemmerson R, Wang X (1996) Induction of apoptotic program in cell-free extracts: requirements of dATP and cytochrome c. Cell 86:147-157.

Lynch G, Larson J, Kelso S, Barrionuevo G, Schottler F (1983) Intracellular injections of EGTA block induction of hippocampal long-term potentiation. Nature 305:719-721.

Macaya A, Munell F, Reventos J, Ferrer I (1996) Molecular factors of cerebral hypoxia-ischemia. Rev Neurol 24:855-864.

Mattson MP (1988) Neurotransmitters in the regulation of cytoarchitecture. Brain Res Rev 13:179-212.

Mattson MP (1992) Calcium as sculptor and destroyer of neural circuitry. Exp Gerontol 27:29-49.

Mattson MP (1994) Calcium and neuronal injury in Alzheimer's disease. Contributions of beta-amyloid precursor protein mismetabolism, free radicals, and metabolic compromise. Ann NY Acad Sci 15:50-76.

Mattson MP, Cheng B (1993) Growth factors protect neurons against excitotoxic/ischemic damage by stabilizing calcium homeostasis. Stroke 24:1136-1140.

Mattson MP, Guthrie PB, Kater SB (1988) Intracellular messengers in the generation and degeneration of hippocampal neuroarchitecture. J Neurosci Res 21:447-464.

Mattson MP, Zhang Y, Bose S (1993) Growth factors prevent mitochondrial dysfunction, loss of calcium homeostasis, and cell injury, but not ATP depletion in hippocampal neurons deprived of glucose. Exp Neurol 121:1-13.

Mayer ML, Westbrook GL, Guthrie PB (1984) Voltage-dependent block 
by $\mathrm{Mg}^{2+}$ of NMDA responses in spinal cord neurons. Nature 309:261-263.

Mestadagh N, Wülfert E (1999) Bicuculine increases $\mathrm{Ca}^{2+}$ transients in rat cerebellar granule cells through non-GABA $\mathrm{GA}_{\mathrm{B}}$ receptor associated mechanisms. Neurosci Lett 265:95-98.

Moran J, Pasantes-Morales H (1991) Taurine-deficient cultured cerebellar astrocytes and granule neurons obtained by treatment with guanidinoethane sulfonate. J Neurosci Res 29:533-537.

Nicolls DG, Akerman KEO (1982) Mitochondrial calcium transport. Biochim Biophys Acta 683:57-88.

Nowak L, Bregestovski P, Ascher P, Herbet A, Prochiantz A (1984) Magnesium gates glutamate-activated channels in mouse central neurones. Nature 307:462-465.

Olney JW, Price MT, Salles KS, Labruyere J, Ryerson R, Mahan K, Frierdich G, Samson L (1987) L-Homocysteic acid: an endogenous excitotoxic ligand of the NMDA receptor. Brain Res Bull 19:597-602.

Palkovits M, Elekes I, Lang T, Patthy A (1986) Taurine levels in discreet brain nuclei of rats. J Neurochem 47:1333-1335.

Pechan PA, Chowdhury K, Seifert W (1992) Free radicals induce gene expression of NGF and bFGF in rat astrocyte culture. NeuroReport 3:469-472.

Peng LA, Juurlink BH, Hertz L (1991) Differences in transmitter release, morphology, and ischemia-induced cell injury between cerebellar granule cell cultures developing in the presence and in the absence of a depolarizing potassium concentration. Dev Brain Res 63:1-12.

Quesada O, Huxtable RJ, Pasantes-Morales H (1984) Effect of guanidinoethane sulfonate on taurine uptake by rat retina. J Neurosci Res 11:179-186.

Quinn MR, Miller CL (1992) Taurine allosterically modulates flunitrazepam binding to synaptic membranes. J Neurosci Res 33:136-141.

Rosenberg PA (1991) Accumulation of extracellular glutamate and neuronal death in astrocyte-poor cortical cultures exposed to glutamine. Glia 4:91-100.

Rosenberg PA, Aizenman E (1989) Hundred-fold increase in neuronal vulnerability to glutamate toxicity in astrocyte-poor cultures of rat cerebral cortex. Neurosci Lett 103:162-168.

Rosenberg PA, Li Y (1995) Adenylyl cyclase activation underlies intracellular cyclic AMP accumulation, cyclic AMP transport, and extracellular adenosine accumulation evoked by beta-adrenergic receptor stimulation in mixed cultures of neurons and astrocytes derived from rat cerebral cortex. Brain Res 692:227-232.

Saransaari P, Oja SS (1997) Enhanced taurine release in cell damaging conditions in the developing and ageing mouse hippocampus. Neuroscience 79:847-854.

Schinder AF, Olson EC, Spitzer NC, Montal M (1996) Mitochondrial dysfunction is a primary event in glutamate neurotoxicity. J Neurosci 16:6125-6133.

Segovia G, Del Acro A, Mora F (1997) Endogenous glutamate increases extracellular concentrations of dopamine, GABA and taurine through
NMDA and AMPA/kainate receptors in striatum of the freely moving rat: a microdialysis study. J Neurochem 69:1476-1483.

Siesjo BK (1988) Historical overview. Calcium, ischemia, and death of brain cells. Ann NY Acad Sci 522:638-661.

Stout AK, Raphael HM, Kanterewicz BI, Klann E, Reynolds IJ (1998) Glutamate-induced neuron death requires mitochondrial calcium uptake. Nat Neurosci 1:366-373.

Sturman JA (1993) Taurine in development. Physiol Rev 73:119-147.

Susin SA, Zamzami N, Castedo M, Hirsch T, Marchetti P, Macho A, Daugas E, Geuskens M, Kroemer G (1996) Bcl-2 inhibits the mitochondrial release of an apoptogenic protease. J Exp Med 184:1331-1341.

Trenkner E (1990) Possible role of glutamate with taurine in neuron-glia interaction during cerebellar development. Prog Clin Biol Res 351:133-140.

Trenkner E (1991) Cerebellar cells in culture. In: Culturing nerve cells (Banker G, Goslin K, eds), pp 283-307. Cambridge, MA: MIT.

Trenkner E, Dykens JA (1986) Taurine moderates kynurenine excitotoxicity in vitro. Soc Neurosci Abstr 16:29.

Trenkner E, Sidman RL (1977) Histogenesis of mouse cerebellum in microwell cultures: cell reaggregation and migration, fiber and synapse formation. J Cell Biol 75:915-940.

Trenkner E, Smith D, Segil N (1984) Is cerebellar granule cell migration regulated by an internal clock? J Neurosci 4:2850-2855.

Trenkner E, Liu D, Harris C, Sturman J (1994) Regulation of protein kinase $\mathrm{C}$ activity by taurine and beta-alanine during excitotoxicity in cat and mouse cerebellar cultures. Adv Exp Med Biol 359:309-316.

Trenkner E, El Idrissi A, Harris C (1996) Balanced interaction of growth factors and taurine regulate energy metabolism, neuronal survival and function of mouse cerebellar granule cells under depolarizing conditions. Adv Exp Med Biol 403:507-517.

Trenkner E, El Idrissi A, Dumas R, Rabe A (1998) Functional consequences of calcium uptake modulation by taurine in vivo and in vitro. Adv Exp Med Biol 442:277-284.

Valiçelebi G, Stauderman K, Varney MA, Akong M, Hess SD, Johnson EC (1998) Fluorescence techniques for measuring channel activity. Methods Enzymol 294:20-47.

Watkins JC, Evans RH (1981) Excitatory amino acid transmitter. Annu Rev Pharmacol Toxicol 21:165-204.

White RJ, Reynods IJ (1995) Mitochondria and $\mathrm{Na}^{+} / \mathrm{Ca}^{2+}$ exchange buffer glutamate-induced calcium loads in cultured cortical neurons. J Neurosci 15:1318-1328.

White RJ, Reynods IJ (1996) Mitochondrial depolarization-in glutamate stimulated neurons: an early signal specific to excitotoxin exposure. J Neurosci 16:5688-5697.

Wood AM, Tiwari P, Bristow DR (1997) Media composition modulates excitatory amino acid-induced death of rat cerebellar granule cells. Hum Exp Toxicol 16:350-355. 